\title{
The Calculation Methodology of the Synergistic Effect of Digitalization of Retail Services
}

\author{
Irina Akhmetova ${ }^{1, *}$ Julya Valeeva $^{1}$ Aigel Sabirzyanova ${ }^{1}$
}

\author{
${ }^{1}$ Kazan State Power Engineering University, Kazan 420066, Russian Federation \\ *Corresponding author. Email: irina_akhmetova@mail.ru
}

\begin{abstract}
The article presents the results of the analysis of the state and future development of digital technologies in the world market in the retail system. The essence of synergy efficiency interconnected retail development in communication and digital technologies, which can be taken by using valuation techniques that take into account various shapes and direction of the social and economic effect. The value of RTN services will be qualitatively different from the services provided by the mass of trade organizations as a whole. The economic nature of such a difference becomes the already noted differentiation of their composition. The difference between these values at the industry level means, all other things being equal, the presence of a network effect from the activities of the RTN. It is reflected in the increase in the value of the final product-a retail service created as a whole as a result of an increase in the number of consumers. It has been justified that the difference in input prices for a commodity flow forms a network effect. The indicator of a monopoly low buyer's cost is more difficult to calculate. Besides, it is necessary to take into account the economies of scale from reducing the cost of services within the network.
\end{abstract}

Keywords: Digital technologies, digital economy, development prospects, synergistic nature of efficiency, interconnected management system, retail.

\section{INTRODUCTION}

The importance of digital technologies in the economy and society is multifaceted and has far-reaching consequences [1]. Thence, digitalization of the production of goods in the coming years will change the structure of its factors to the minimum level of use of the human factor in production and logistics processes, will ensure the total integration of end-to-end production and logistics chains, a fundamentally new quality of management decisions through the use of data and digital models [2].

Digital platforms are created to develop digital business solutions and government control. They combine digital models, work environments, data, business offerings with the technological capabilities of the internet of things, cloud resources, smart hardware, and cybersecurity. Complete integration of processes and functions within the enterprise contributes to integration into the digital economy, rapid implementation of digital innovations, high speed of changes in the production processes and business models, and lower costs of the digitalization of companies [3-5].

The analysis of Russian and foreign practice as well as theoretical studies demonstrate that development of services and digital transformation of socio-economic systems are carried out based on digital platforms that integrate economic, social and technological processes that form digital service ecosystems. In this regard, a new institution has emerged in the economy and a new category of business structures in the service sector known as service integrators, which has an increasingly important role in progressive economic development. But the mechanisms of the service integrators of functioning, management methods, network service interaction with other economic entities and many other issues are remained insufficiently studied and hinder in practice the development of companies, that is to say, the service integrators.

\section{LITERATURE REVIEW}

The interest of a general methodological and theoretical nature for the understanding of the problem by the authors was formed by the fundamental works of such foreign authors as Rese [1], Queille and Sifakis [2], Willems [3], Hagberg et al. [4], Kaushik and Rahman [5], Pantano et al. [6], Lola and Bakeev [7], Agrawal et al. [8], Reinartz et al. [9], Kuzovkova et al. [10]. The study aims to develop theoretical foundations and methodological provisions, as well as scientific and practical recommendations for managing the digital transformation of retail chain services with the effective implementation of the network effect.

The author's approach to the definition of digital transformation formulates as a radical transformation process of the concept and format of the functioning of socio-economic systems at all levels, the difference of which is the dualistic consideration of digital transformation. On the one hand, as a technical and economic process of digitization, in other words, the transfer of all resources into digital format, the introduction, and formation of a pool of digital technologies. On the other hand, as an organizational and 
economic process of digitalization, that means the creation of network service platforms for the integration and interaction of users of digital technologies. The interrelation and interdependence of digital transformation processes and the tendencies of services development of the economy were proved, a system of factors and conditions for digital transformation in modern conditions was formed.

An approach to the essence and method of assessing the synergistic effect in the organization of digitalization of retail trade networks has been proposed.

\section{ANALYSIS OF GLOBAL TRENDS IN THE DEVELOPMENT OF DIGITAL TECHNOL- OGIES}

The development of the digital economy is based on innovative digital technologies, including distributed data processing technologies, in which computer resources and capacities are provided to the user as an Internet service (cloud services); neurotechnology and artificial intelligence; intelligent systems that use a combination of big data analytics, cloud computing, machine-to-machine connectivity and the Internet of Things for work and learning; production technologies, including cyber-physical systems, sensor technologies, 3D printing, computer engineering, robotics, qualitatively different production resources (nanotechnology and new materials), and others [11].

Following national projects and the Digital Economy of the Russian Federation program, 9 key end-to-end digital technologies had been taken to analyze the trends and consequences of development. Table 1 shows the dynamics of the achieved and projected levels of world development of digital technologies for 2018-2025 [12].
Analysis of the dynamics of the development of digital technologies in world markets indicates the progressive nature of scientific and technological progress (STP) in this area. In seven years, digital technologies will increase the market size by 35 times [13].

To adapt the methodology for analyzing the external environment, it is necessary, first of all, to identify and classify the manifestations of "numbers" at various levels of management. Initially, it is necessary to determine the backbone factors of the formation of the digital economy:

- Formation of a qualitatively new structure of economic assets that meet the economic priorities of the digital economy;

- Use of electronic technologies and services;

- Collection and processing of large amounts of data in digital form;

- Formation and support of favorable organizational, infrastructure, and regulatory characteristics of the development of digital technologies;

- Development of institutions of the digital economy;

- Preservation of the sovereignty of countries in the context of economic globalization;

- Ensuring information and economic security of the state and business;

- Assistance in improving the quality of life of citizens;

- Protection of personal data and privacy of citizens in the digital space.

Such a variety of factors, despite the direct relationship with information technologies, influenced the identification of the digital economy itself in various documents and studies of specialists and experts (see Table 1) [12].

Table 1 Dynamics of the achieved and projected levels of world development of digital technologies

\begin{tabular}{|c|c|c|c|c|c|c|c|c|c|}
\hline \multirow{2}{*}{ Name of digital technologies } & \multicolumn{7}{|c|}{ World market volume (USD billion) by years } & $\begin{array}{c}\text { Rate of change, } \\
\%\end{array}$ \\
\cline { 2 - 12 } & 2018 & 2019 & 2020 & 2021 & 2022 & 2023 & 2024 & 2025 & \\
\hline 1. Big data & 38 & 46 & 54 & 65 & 77 & 92 & 110 & 132 & 347,4 \\
\hline 2.Quantumtechnology & 0,86 & 1,13 & 1,48 & 1,95 & 2,57 & 3,38 & 4,45 & 5,85 & 503,1 \\
\hline 3.Robotics and sensorics & 48 & 57 & 67 & 78 & 91 & 107 & 126 & 147 & 306,3 \\
\hline 4.Artificial Intelligence & 21 & 29 & 40 & 55 & 75 & 102 & 140 & 191 & 397,9 \\
\hline 5.Computer Engineering & 1980 & 2080 & 2190 & 2300 & 2410 & 2530 & 2660 & 2790 & 140,9 \\
\hline 6.Industrial Internet & 168 & 214 & 274 & 350 & 447 & 572 & 731 & 934 & 556,0 \\
\hline 7. Blockchain & 0,6 & 1,0 & 1,8 & 3,1 & 5,4 & 9,3 & 16,2 & 28,3 & 4716,7 \\
\hline 8.Wireless connection & 300 & 270 & 170 & 145 & 110 & 75780 & 70750 & 50700 & $16,7122,8$ \\
& 570 & 600 & 700 & 7205 & 77010 & 15 & 30 & 50 & \\
\hline 9.Virtual and augmented reality technologies & 27 & 44 & 71 & 116 & 188 & 307 & 500 & 815 & 3018,5 \\
\hline
\end{tabular}

The highest rates of development in the future until 2025. typical for technologies: blockchain (47.2 times), virtual and augmented reality (30.2 times), and wireless
5G (100 times over five years). Digital technologies such as industrial Internet (556\%), quantum technologies $(503 \%)$, artificial intelligence $(397.9 \%)$, big data 
$(347.4 \%)$, robotics and sensors $(306.3 \%)$ are at the average level of growth rates of the global market. Computer engineering, which already occupies almost half of the global digital technology market, is expected to increase by 1.4 times by 2025 .

In the wireless sector, there is a tendency to reduce the share of mobile communication standards of the first generations ( $2 \mathrm{G}$ and $3 \mathrm{G})$ by six times and the growth of the new standard of the fourth and especially fifth generations. So, by 2025 , the number of connections to $5 \mathrm{G}$ wireless networks will grow to 2.6 billion.

\section{DIGITALIZATION OF SERVICES IN RE- TAIL}

The goal of IT solutions in retail is to promote revenue growth and customer loyalty. This situation is being achieved by improving the efficiency of communication with customers and reducing marketing costs.

Interaction with the buyer is a "sore" question of stores. If online companies have learned to keep track of what products a site visitor was interested in order to select the most relevant offers for him and return him to the site with a discount offer. Sometimes in a shopping center, there isn't even a seller next to the buyer who could quickly help, answer questions about the product, or customer comes to a store after seeing an advertisement but cannot find the desired good. As a result, it turns out that trading companies invest in marketing but cannot provide the quality of service in their stores and, thus, lose part of their revenue.

Digital tools today help to reduce the cost of attracting customers to stores and automate business processes in sales halls:

1. The Digital Signage system combines video screens, interactive storefronts, and other digital outdoor advertising into a network manageability content from the center. The company saves on printing and transmits information to customers more quickly.

2. Smart counters with Touch \& Learn technology can display information on the screen near the product after the customer has taken it from the shelf.

3. Video analytics technologies in the retail show whether the store visitors notice the content on the screen (determine the direction of gaze, gender, approximate age, estimate the number of people in the queue);

4. WiFi analytics helps you identify loyal customers, evaluate the effectiveness of advertising campaigns, and monitor the most popular areas in stores to place the right products in them. This solution is allowed you to collect data about the time spent in the store, repeated visits thanks to the storage of mobile devices of visitors. Therefore,
WiFi analytics is useful when you are planning the schedules of sales consultants. If you know the specifics of store traffic at different times of the day during peak hours, you could increase the number of employees in the halls.

The most standard and demanded IT product for Russian retailers is a CRM system that allows you to maintain a customer base, receive requests from them, segment customers and their needs, offer personalized programs loyalty. CRM-solution is allowed us to manage relationships with a supplier, loyalty program, maintain a warehouse, contractual activities, integrate with government agencies information systems for the exchange of information, and analyze demand, markets and sales. The IT product is an ERP system for retail.

Online e-commerce systems allow retailers to collect large amounts of heterogeneous data about user behavior and preferences. Large retailers can use both their resources for deploying e-commerce systems, big data analytics, and using cloud technologies to store their solutions and data collected when working with various stakeholders at the same time. The trend of outsourcing data storage and deployment of information systems that provide business logic for an online retailer has manifested itself in Russia in an environment of increasing competition and lack of sufficient economic growth.

A necessary for retail is the optimal load balancing of an IT-based solution such as a load balancing system personnel (personnel management system). The system allows you to automatically solve several tasks that are related to human resource management.

The system allows you to automatically solve several tasks related to human resource management, including calculating the optimal number of employees depending on the degree of the availability of the point of sale and forming the staff work schedule taking into account planned vacations, legal restrictions, and employee competencies. This system as well as provides ample opportunities for analysis and forecasting thanks to the analytical module. Biometric identification of employees could also include the functionality of the solution when entering the system, which would allow controlling the actual working time of each employee.

A notable technological trend in retail is the personalization of user preferences and the provision of omnichannel management of complex personalized sales in realtime (omnichannel platform). From the point of view of the contact center operator, any user action on the site, an appeal via SMS, phone, email, social media, or any other channel for interaction should be recorded, and should also lead to effective processing of the user's request, for example, increase sales, provide necessary consultations, etc.

In this case, the IT solution is an integration platform that solves the above tasks: optimization of the flow of 
calls by choosing the best communication channel, optimization the workload of operators, and personalizes the dialogue with the user. The platform for the implementation of omnichannel integrates into the retailer's IT infrastructure, links establish for data exchange with other modules - BI, CRM, electronic document management system, etc.

Well-known Retail Representatives in Russia (X5 Retail Group, CocaCola, OJSC Seventh Continent, LLC Adidas, L'Etoile) are implementing digitalization and digital transformation processes with the help of the service integrator of the NAS Group. These several services companies ensure effective work with analytics increasing the validity of management decisions, both in the long term and in operational activities. Many services aim at supporting the software and user parts of automated workstations, efficient management of electronic trading equipment (including fiscal registrars), self-service devices, video surveillance systems, others. transformation processes of designated retail representatives allowed these companies to achieve significant competitive advantages in their market niches, strengthen their positions and expand their market share, judging by the main indicators of their activities.

\section{THE SYNERGISTIC NATURE OF THE EFFECTIVENESS OF THE USE OF DIGI- TAL TECHNOLOGIES}

The use of digital technologies in the economy and society has a multifaceted and multidirectional impact on the nature and factors of production and consumption of goods and services. The positive effects of digital transformation are evident at all levels of the socio-economic system, from the individual consumer to the country as a whole (see Table 2).

An active position in the implementation of digital

Table 2 The positive effect sand benefits of the digital transformation in the socio-economic systems

\begin{tabular}{|c|c|c|}
\hline \multicolumn{3}{|c|}{ EFFECTS OF DIGITAL TRANSFORMATION FOR THE COUNTRY AS A WHOLE } \\
\hline \multicolumn{3}{|c|}{ New positive net effect on the number of jobs } \\
\hline \multicolumn{3}{|c|}{ Improving resource efficiency } \\
\hline $\begin{array}{c}\text { SECTOR } \\
\text { EFFECTS FOR THE PUBLIC }\end{array}$ & $\begin{array}{c}\text { EFFECTS FOR ENTERPRISES OF } \\
\text { COMPANIES }\end{array}$ & EFFECTS FOR CONSUMERS \\
\hline $\begin{array}{c}\text { Improving process efficiency } \\
\text { abuse in obtaining public services }\end{array}$ & $\begin{array}{c}\text { Simplified expansion to other markets, } \\
\text { revenue growth } \\
\text { cesses (for example, supply chain man- } \\
\text { agement) }\end{array}$ & $\begin{array}{c}\text { The opportunity to purchase the best products } \\
\text { and services at the most favorable prices }\end{array}$ \\
\hline $\begin{array}{c}\text { Better engagement with citizens and the } \\
\text { private sector }\end{array}$ & $\begin{array}{c}\text { Access to the best workforce through the } \\
\text { use of digital communication channels }\end{array}$ & $\begin{array}{c}\text { Getting information about the most interesting } \\
\text { opportunities for employment }\end{array}$ \\
\hline $\begin{array}{c}\text { Identifying and analyzing social trends } \\
\text { with big data }\end{array}$ & $\begin{array}{c}\text { Increasing transparency and ease of inter- } \\
\text { action with the public sector }\end{array}$ & $\begin{array}{c}\text { Facilitating access to government services } \\
\text { through digital portals }\end{array}$ \\
\hline
\end{tabular}

Based on the established conclusions, the synergistic network effect will consist of the nested values of all participants in the chain of the total consumer value of the RTN service.

$\mathrm{SNE}_{\mathrm{RTN}}=\mathrm{f}\left(\mathrm{CV}_{\mathrm{s}}, \mathrm{CV}_{\text {cons }}, \mathrm{CV}_{\text {sa }}, \mathrm{CV}_{\text {prod }}, \mathrm{CV}_{\text {a.p. }}, \mathrm{CV}_{\mathrm{c}}, \mathrm{CV}_{\mathrm{i}}\right.$, $\left.\mathrm{CV}_{\mathrm{o}}, \mathrm{CV}_{\mathrm{s}}, \mathrm{CV}_{\text {s.p }}\right)(\mathbf{1})$

Where $\mathrm{SNE}_{\mathrm{RT}}$ - synergistic network effect
$\mathrm{CV}_{\mathrm{s}}$ - the contribution of society to the total consumer value of the retail trade network service,

$\mathrm{CV}_{\text {cons }}$-consumer contribution to the aggregate consumer value of a retail network service,

$\mathrm{CV}_{\mathrm{sa}}$-the contribution of state authorities to the total consumer value of a retail chain service,

$\mathrm{CV}_{\text {prod }}$-the contribution of manufacturers to the total consumer value of a retail chain service, 
$\mathrm{CV}_{\text {a.p }}-$ the contribution of agricultural producers to the total consumer value of retail trade network services,

$\mathrm{CV}_{\mathrm{c}}$-the contribution of converters to the aggregate consumer value of the retail trade network service,

$\mathrm{CV}_{\mathrm{i}}$-Investors' contribution to the total consumer value of the retail trade network service,

$\mathrm{CV}_{\mathrm{o}}-$ Contribution of RTN owners to the total consumer value of the retail trade network service,

$\mathrm{CV}_{\mathrm{s}}$-contribution of staff to the total consumer value of the retail network service,

$\mathrm{CV}_{\text {s.p }}-$ contribution of service providers to the aggregate consumer value of the retail network service.

Figure 1 shows an additive approach to determining the total value of RTN services. Assessing the cumulative effect of a retail chain conceptually reflects differences in the categories of a retail chain and its services.

The network effect of the provision of services is based on the existence of a number of their features, which are summarized based on the analysis of the RTS activities:

- The service can be unified, standardized and replicated (as a rule);

- The service can be tailored to the needs of consumers;

- Services of retail chains of the same format are identical;

These services are of a corporate and local nature. It reflects in the services industries under the corporate and operational strategies of each outlet and the network. The synergy consists in combining assets and increasing capitalization, saving due to scale growth, reducing transaction costs, improving the quality of management [5], implementing unified information systems and services to respond to changes in the structure of consumption, consumer preferences, increasing the level of service; using new formats and service technologies. The results of studying the synergistic effect [6] for trade formations are reflected in the works of many scientists. Based on the developments on the systematization of forms of synergistic effect we have identified the forms of manifestation of the effect of synergy in the activities of retail chains. These forms are presented in Table 3.

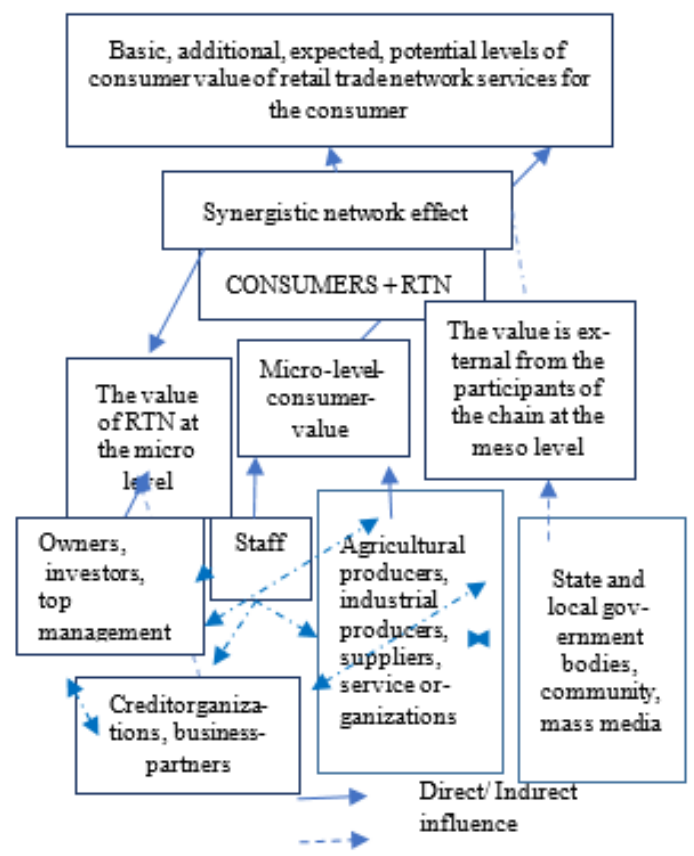

Figure 1 The relationship of participants in the chain of total consumer value of a retail network service in the formation of a synergistic network effect Source: compiled by the author.

Table 3 The main elements of the cumulative effect of the network in the network activities

\begin{tabular}{|c|c|c|c|c|c|}
\hline $\begin{array}{l}\text { Network effect recip- } \\
\text { ients }\end{array}$ & Strategic & Operational & Financial & Social Market & $\begin{array}{c}\text { Business } \\
\text { Reputation }\end{array}$ \\
\hline $\begin{array}{l}\text { RTN-manufacturers- } \\
\text { processors-production } \\
\text { companies }\end{array}$ & $\begin{array}{l}\text { Long-term sales } \\
\text { channels }\end{array}$ & $\begin{array}{l}\text { Economies of scale and } \\
\text { reduced trading costs }\end{array}$ & $\begin{array}{l}\text { Changes in the vol- } \\
\text { ume and structure of } \\
\text { own and borrowed } \\
\text { funds }\end{array}$ & $\begin{array}{l}\text { Increasing the den- } \\
\text { sity of consumer } \\
\text { coverage }\end{array}$ & $\begin{array}{l}\text { Entering new mar- } \\
\text { kets with minimal } \\
\text { investment }\end{array}$ \\
\hline $\begin{array}{l}\text { RTN - consumers - } \\
\text { service providers-soci- } \\
\text { ety-investors }\end{array}$ & $\begin{array}{c}\text { Long-term relation- } \\
\text { ships with consum- } \\
\text { ers }\end{array}$ & $\begin{array}{l}\text { Reduce costs through } \\
\text { more efficient equip- } \\
\text { ment loading }\end{array}$ & $\begin{array}{c}\text { Reduce supply costs } \\
\text { by putting pressure } \\
\text { on suppliers }\end{array}$ & $\begin{array}{l}\text { Loyalty } \\
\text { to the brand }\end{array}$ & $\begin{array}{c}\text { More attractive part- } \\
\text { ner and investment } \\
\text { object }\end{array}$ \\
\hline $\begin{array}{l}\text { RTN-Manufacturers- } \\
\text { processors-production } \\
\text { companies - state au- } \\
\text { thorities }\end{array}$ & $\begin{array}{l}\text { Long-term relation- } \\
\text { ships with suppliers } \\
\text { of raw materials and } \\
\text { products }\end{array}$ & $\begin{array}{l}\text { Distribution centers, } \\
\text { communications within } \\
\text { the network, standardi- } \\
\text { zation of business pro- } \\
\text { cesses }\end{array}$ & $\begin{array}{l}\text { Lower prices due to } \\
\text { low purchase prices, } \\
\text { high sales volume }\end{array}$ & $\begin{array}{l}\text { The social responsi- } \\
\text { bility of the busi- } \\
\text { ness contributes to } \\
\text { the growth of its } \\
\text { business reputation } \\
\text { and the capitaliza- } \\
\text { tion of the company }\end{array}$ & $\begin{array}{l}\text { Mitigating the im- } \\
\text { pact of business risk } \\
\text { factors }\end{array}$ \\
\hline $\begin{array}{l}\text { RTN-manufacturers- } \\
\text { processors-production } \\
\text { companies-govern- } \\
\text { ment authorities }\end{array}$ & $\begin{array}{c}\text { Long-term relation- } \\
\text { ships with counter- } \\
\text { parties }\end{array}$ & $\begin{array}{l}\text { Reduction of transac- } \\
\text { tion costs }\end{array}$ & $\begin{array}{l}\text { Minimization of } \\
\text { taxation }\end{array}$ & $\begin{array}{l}\text { Customer satisfac- } \\
\text { tion }\end{array}$ & $\begin{array}{l}\text { Creation of new ad- } \\
\text { ditional services }\end{array}$ \\
\hline $\begin{array}{l}\text { RTS - consumers - } \\
\text { service providers - so- } \\
\text { ciety - investors }\end{array}$ & Market share growth & $\begin{array}{l}\text { Reduce staff costs by } \\
\text { eliminating duplicate } \\
\text { functions }\end{array}$ & $\begin{array}{l}\text { Growth in the value } \\
\text { of assets }\end{array}$ & Staff satisfaction & $\begin{array}{l}\text { Centralization of } \\
\text { marketing or sales } \\
\text { synergies }\end{array}$ \\
\hline
\end{tabular}


The recipient of the network effect will be all participants, as summarized in Table 3 above.

The value phenomenon of a retail trade network service is viewed through the prism of the network effect obtained by a retail trade network, as a mechanism for adding value in the chain of creating the aggregate consumer value of a retail trade network service with a focus on consumers and all its participants.

Thus, new methods of assessing socio-economic benefits are required. They should take into account the increase in the value of trade services through CSR strategies. It is necessary to note the component of the total consumer value of the retail network after considering the expectations and obtaining the values. Each participant receives benefits in terms of value. The consumer value of service can be estimated in value terms for a specific buyer and the retail chain in general.

The first element is consumer value research. The value received by a consumer in a retail network consists of the value of the purchased goods and the value of the trade service.

The measured cost consists of two parts: the cost of products sold and the consumer value of the service. The higher the level of consumer value, the higher the level of the trade margin. Retail value-added service is the value or benefit that consumers receive when they receive retail network services.

\section{CONCLUSIONS}

The analysis of the state and prospects for the development of digital technologies in the world market has demonstrated the presence of progressive trends and their system-forming influence on the economy and society. The systematization of the sources, needs of the digital economy, and the results of the creation, application, and development of digital technologies revealed a high degree of their correlation.

The application and dissemination of digital technologies not only ensure internal and external socio-economic efficiency at different levels of management but also launch the processes of updating the digital and related technologies themselves, their components, identification tools, visualization, analytics, cybersecurity, expanding markets for the production of digital goods and services, factors of production and labor, media market.

The disclosure of a multifactorial and multidimensional system of consequences of the use and development of digital technologies makes it possible to form a complex of indicators of synergistic efficiency and evaluate it for individual technologies or their combination. It provides the basis for making informed management decisions to regulate digital development processes. The authors have developed an integrated approach while maintaining the general methodology and algorithm, which involves the development of a list of indicators of synergetic efficiency adequate to the object under study, which will be presented in the following publications of the authors.

Development management services retail chains leads to a synergistic network effect, as a result, to enhance the delivery of services to retail chains for stakeholders members of the chain.

The main components of the synergistic network effect of the retail trade network service are summarized. The network effect of the provision of services is based on the existence of a number of their features which are summarized on the basis of the analysis of the RTS activities.

\section{REFERENCES}

[1] A. Rese, How augmented reality apps are accepted by consumers: A comparative analysis using scales and opinions, Technological Forecasting and Social Change 124 (2017) 306-319.DOI: 10.1016/j.techfore.2016.10.010

[2] J.P. Queille, J. Sifakis, Specification and verification of concurrent systems in CESAR, in: M. DezaniCiancaglini and U. Montanari (Eds.), Proceedings of the 5th International Symposium on Programming, Lecture Notes in Computer Science, vol. 137, Springer, Berlin, Heidelberg, 1982, pp. 337-351. DOI: https://doi.org/10.1007/3-540-11494-7_22

[3] K. Willems, The path to purchase is paved with digital opportunities: An inventory of shopper-oriented retail technologies, Technological Forecasting and Social $\begin{array}{llll}\text { Change } & 124 & \text { (2017) 228-242. DOI: }\end{array}$ https://doi.org/10.1016/j.techfore.2016.10.066

[4] J. Hagberg, M. Sundstrom, N. Egels-Zandén, The digitalization of retailing: an exploratory framework, International Journal of Retail \& Distribution Management 44(7) (2017) 694-712. DOI: https://doi.org/10.1108/IJRDM-092015-0140

[5] A. Kaushik, Z. Rahman, An alternative model of selfservice retail technology adoption, Journal of Services Marketing 29(5) (2015) 406-420. DOI: https://doi.org/10.1108/JSM-08-2014-0276

[6] E. Pantano, C. Priporas, N. Stylos, Knowledge Push Curve (KPC) in retailing: Evidence from patented innovations analysis affecting retailers' competitiveness, Journal of Retailing and Consumer Services 44 (2018) 150-160. DOI: https://doi.org/10.1016/j.jretconser.2018.06.004 
[7] I.S. Lola, M.B. Bakeev, Effects of Influence of Economic and Technological Development of IT Segment on Digital Transformation of Retail Trade, Voprosy Statistiki 26(11) (2019) 18-35. DOI: https://doi.org/10.34023/23136383-2019-26-11-18-35

[8] R. Agrawal, T. Imielinski, A. Swami, Mining association rules between sets of items in large databases, in: Proceedings of the International Conference on Management of Data (SIGMOD), vol. 22, ACM SIGMOD Record, Washington D.C., 2013, pp. 207-216. DOI: https://doi.org/10.1145/170035.170072

[9] W. Reinartz, N. Wiegand, M. Imschloss, The Impact of Digital Transformation on the Retailing Value Chain, International Journal of Research in Marketing 36(3) (2019) 350-366. DOI: https://doi.org/10.1016/j.ijresmar.2018.12.002

[10] T. Kuzovkova, D. Kuzovkov, O. Sharavova, Transformation of criteria and indicators of digital development of economy and information society, in: Proceedings of the 24th Conference of Open Innovations Association, vol.97, FRUCT, pp. 682-687.

[11] W. Strielkowski, D. Streimikiene, A. Fomina, E. Semenova, Internet of energy (IoE) and high-renewables electricity system market design, Energies 12(24) (2019), 4790. DOI: https://doi.org/10.3390/en12244790

[12] OECD (2019) Productivity Growth in the Digital Age. from: https://www.oecd.org/going-digi-tal/productivity-growth-in-the-digital-age.pdf Accessed 30 Nov 2020

[13] UNCTAD (2019) Digital Economy Report 2019. Value Creation and Capture: Implications for Developing Countries. https://unctad.org/en/PublicationsLibrary/der2019_en.pdf Accessed 30 Sep 2020 